however, it is necessary to cleange the general cavity, the 0.6 per cent, salt solution at hlood-heat should he employed. Drainage will be necessary if a noxious material is left in the peritoneal cavity, or if it is expected that an extensive effusion will follow. Ohjection is made to the glass drainage-tube on account of its rigidity. The fenestrated rubher tube meets all indications, and is free from this objection; occasionally the use of strips of iodoform gauze will hest secure the necessary drainage.

In conclusion, the author remarks that the surgeon's position with regard to peritonitis is, at the present time, similar to that which obtained some thirty years ago in regard to external inflammations. His efforts are directed against the effects of damage already done, rather than toward measures of prevention.

\title{
OBSTETRICS.
}

\section{UNDER THE CHARGE OF}

EDWARD P. DAVIS, A.MF., M.D.,

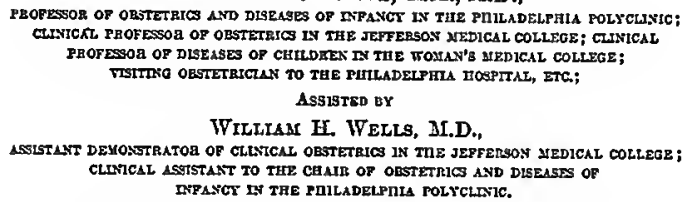

Wrumar H. WELLS, AI.D.,


CLMHCAL ASTSTAST TO THE CBAIR OF ORSTETRICS AND DLSEASTS OF

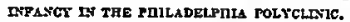

\section{Two Crasareay Sections fon Cicataiclal Stexosis of the Soft Parts.}

KAyser (Zeitschrift für Geburtshülfe und Gynälologie, Band xxvii.; Heft 2) reports in detail the histories of two crses operated on at the University Frauenklinic at Giessen. The first patient was twenty-nine years old and at the end of her second pregnancy. In her first lahor the child had apparently heen extracted by forceps after cephalotripsy had heen performed, and six weeks later the patient had been operated on for vesico-vaginal fistula by Prof. Löhlein, with favorable result. On vaginal examination it was found that the vagina was nartowed, and stretching from the cervix hackward and on all sides were strong bands of cicatricial tissue. On the anterior vaginal wall the cicatrix of the old operation for vesico-vaginal fistula existed as a hard swelling. A true portio was not present, hut in place of it there existed only a flat projection, in which, high up toward the promontory, the external os uteri existed as a small shallow cavity. A douhle promontory with some sacral lordosis were present. Induction of lahor by means of hot and cold vaginal donches, tampons, etc., was tried withont snccess, the cervix being only capahle of a small amount of dilatation, owing to the existing cicatricial tissue. As the patient earnestly desired a living child, and it was feared that deep cervical incision might lead to unfavorable results for mother 
and fotus, the Ciesareas operation was decided oa and performed on the fifth day after the patient's admission, the child heing safely delivered. No uafavorahle symptoms occurred to the mother except slight secoadary hemorrhage from the vagina, which was easily coatrolled hy an ice-hladder and ergot. Both mother and child left the hospital in good coaditiou, though in the former the old sear tissue still remained nnd no portio could he felt.

The second case was a II-gravida, who gave a history of having heen delivered of a dead child hy forceps after a lahor of three days. From this a vesico-vaginal fistula dereloped. The vaginal eatrance, the canal itself, aad in particular the iaferior portion of the recto-vngiaal septum were very much aarrowed hy cicatricial tissue. A urethro-vaginal fistula also existed. Both fistulis were closed hy operation, hut the vaginn remained ia a state of iacomplete ntresia. The patieat'a pelvic measurements were as follows: Sp., 22.3; Cr., 25.5 ; Tr., 29 ; Conj. ext., 18.5. Ia the hope of helping dilatatioa of the soft parts nnd of exciting uteriae coatractioas, warm ragiaal iajections of carbolic acid solution and tampons were tried without success. As it seemed impossible to hriag a living child throagh the unyieldiag cervix nnd vagian, it was decided to do Cresarean section. Coasidernble hemorrhage was eacountered during the operation, but was successfully controlled. The chlld weighcd $1850 \mathrm{gms}$, nad was living. The mother, ofter a somewhat varinble puerperal period, died in coma on the eighth day, aad nt the autopsy the following conditions were found: Fatty degenerntion of the heart with nnxemin of nll the organs. Spleen enlarged, and ia the gall-hladder, which was considerahly enlarged, were found mnny gall-stones. In pieces of the uterine tissue suhjected to bncteriological exnminntion there were fouad in the cadometrium strepto- nd staphylococci with other hacteria, while in the muscular tissue oaly smnll oval forms mere present. A guiaen-pig inoculated from the endometrium died in twenty-four to thirty-six hours, whilst another iato which $n$ solutioa of the muscular tissue was injected remalned healthy. The child of the second patient died of icterus.

\section{Sex Cages of Bright's Diseage in Pregnaxcy and Labor. -}

Herarax, nt a meetiag of the Obstetrical Society of Loadon (Lancet, January 13, 1894), preseated the histories of aix cases of Bright's disense occuring during pregnancy and labor. From the comparisoas of the histories of the ahove nnd others published in the Society's Transaclions, he concludes that there are at lenst two kinds of reaal disense to which n pregaaat woman is especially liahle. One of these is a rery acnte disease in which premonitory symptoms are either nhsent or of du ration measurahle hy hours or days. It attacks chiefly primigravide and often calses intra-uterine denth of the child. The above form of the disease is also nttended with extreme diminntion of the quantity of uriae; the small amount that is passed heiag greatly deficient ia urea, hut coataining enough alhumin to make it solid on hoiliag. This form of disease is accompanied with rapidly oecarring fits; hut if it runs a favorahle course. the fits cease and the urine increases in amoant, the percentage of uren risiag thcrein. If the excretion of urea is not re-estahlished the case quiekly ends fatally. Sach cases aeldom, if ever, pass iato chronic Bright's disesse. The other is $\mathbf{n}$ discase which attncks older suhjects, chiefly 